\title{
Characterization and Proteolytic Origins of Specific Peptides Appearing During Lipopolysaccharide Experimental Mastitis
}

\author{
F. Moussaoui,, ${ }^{\star}$ F. Laurent, ${ }^{\star}$ J. M. Girardet,§ G. Humbert,§ J-L. Gaillard,§ and Y. Le Roux \\ *Laboratoire de Sciences Animales, U.C. INRA 12 340, \\ Ecole Nationale Supérieure d'Agronomie et des Industries Alimentaires (ENSAIA), \\ 54505 Vandoeuvre-lès-Nancy, France \\ $\S$ Laboratoire des BioSciences de l'Aliment, U. C. INRA 885, \\ Faculté des Sciences et Techniques, UHP - Nancy 1 , \\ 54506 Vandoeuvre-lès-Nancy, France
}

\begin{abstract}
Based on the compositional change of the proteose peptone fraction, proteolysis was studied over time following lipopolysaccharide-induced experimental mastitis. Electrophoresis of the proteose peptone fraction revealed many degradation products. Five peptides were identified by amino-terminal sequencing as internal fragments of $\beta-, \kappa^{-}, \alpha_{\mathrm{s} 1^{-}}$, and $\alpha_{\mathrm{s} 2^{-}}$-casein that were generated by somatic cell proteases. Although $\kappa$-casein is considered particularly resistant to endogenous proteolysis, a $\kappa$-casein peptide was electrophoretically isolated in association with a $\beta$-casein fragment. The in vitro kinetic studies of caseinate hydrolysis by elastase, one of the main polymorphonuclear neutrophil (PMN) proteases, suggested that the $\beta$-casein peptide might be generated by elastase. In addition, elastase activity in milk PMN was higher during the inflammation of the mammary gland than prior to infusion.
\end{abstract}

(Key words: casein, endogenous proteolysis, lipopolysaccharide, mastitis)

Abbreviation key: CAPS $=3$-[cyclohexylamino]-1propanesulfonic acid, GMP = glycomacropeptide, LPS = lipopolysaccharide, $\mathbf{M M}=$ molecular mass, $\mathbf{P I}=$ postinfusion, PMN = polymorphonuclear neutrophils, $\mathbf{P P}$ $=$ proteose peptone.

\section{INTRODUCTION}

Milk from healthy bovine mammary glands contains four main types of somatic cells: lymphocytes, polymorphonuclear neutrophils (PMN), macrophages, and secretory epithelial cells (Saad and Stensson, 1990). After intramammary infection, large numbers of PMN are recruited (Sordillo et al., 1997) to the infected gland.

Received March 29, 2002.

Accepted September 6, 2002.

Corresponding author: F. Moussaoui; e-mail: fatima.moussaoui @ensaia.nancy-inpl.fr.
PMN proteolytic enzymes include neutral and acidic proteases. Elastase (E.C. 3.4.21.36) and cathepsin G (E.C. 3.4.21.20) are the predominant enzymes in PMN (Verdi and Barbano, 1991; Owen and Campbell, 1999; Bank and Ansorge, 2001). Other proteases in PMN include the thiol protease cathepsin B (E.C. 3.4.22.1) and the acid protease cathepsin D (E.C. 3.4.23.5), as reported by Owen and Campbell (1999). Furthermore, PMN from cows with mastitis have been reported by $\mathrm{Li}$ et al. (1999) to contain collagenase (E.C. 3.4.24.3). Proteases from PMN contribute to hydrolysis of CN in milk at neutral pH (Verdi and Barbano, 1991) and then possibly in milk with high SCC. Elastase activity on $\alpha_{\mathrm{s} 1^{-}}$ and $\beta$-CN (Considine et al., 1999; 2000) and collagenase activity on $\beta$-CN have been evidenced by modelization studies with somatic cell proteases (Gilles and Keil, 1976). No data have been reported concerning $\kappa$-CN degradation in vivo, and only a few studies have dealt with its capacity to be hydrolyzed in vitro (Larsen et al., 1996).

The main proteolytic enzyme in milk is the alkaline protease, plasmin (E.C. 3.4.21.7), which originates from cow's blood. Plasmin preferentially hydrolyzes $\beta$-CN and generates amino-terminal $\beta$-CN fragments recovered in the proteose peptone (PP) fraction and carboxyterminal fragments named $\gamma$-CNs (Eigel et al., 1984). Proteose peptones are a heat-stable and acid-soluble fraction of milk that can be divided into two groups: The first group is a complex mixture of peptides, mainly $\beta$-CN-5P (f1-105 and 1-107, noted f1-105/7), $\beta$-CN-4P (f1-28), and $\beta$-CN-1P (f29-105/7; Eigel et al., 1984). The second group includes component PP3, a hydrophobic phosphorylated glycoprotein of 135 amino acid residues and a fragment, termed components PP3 (f54-135), resulting from hydrolysis of PP3 by plasmin (Kanno and Ogawa, 1989; Sorensen and Petersen, 1993). The component PP3 and PP3 (f54-135) have apparent molecular masses (MM) of 28 and $18 \mathrm{kDa}$, respectively.

Proteose peptones are considered as indicators of endogenous proteolysis during LPS experimental mastitis (Moussaoui et al., 2002). Endogenous proteolysis is the 
consequence of activities of both plasmin and PMN enzymes. The kinetic of PP concentration in milk shows two maxima: The first one occurs at $8 \mathrm{~h}$ postinfusion (PI) and coincides both with the highest plasmin activity (between 4 and $8 \mathrm{~h}$ PI) and with a high level of SCC (from 4 to $36 \mathrm{~h} \mathrm{PI}$ ). The second one occurs at 25 or 36 $\mathrm{h}$ PI according to the cow studied, and is concomitant with a basic level of plasmin activity while SCC is still high. Thus, the early phase of endogenous proteolysis induced by lipopolysaccharide (LPS) infusion involves both plasmin and somatic cell proteases, while the later phase mainly involves somatic cell proteases.

The aim of this work was to study the composition change of PP fraction during a LPS experimental mastitis. Mastitis induced by $E$. coli endotoxin enables the study of endogenous proteolysis resulting from the action of plasmin and/or somatic cell proteases. Peptides of PP fraction that were specific to the inflammation have been characterized. Several PMN proteases have been tested on a total casein fraction in order to identify the proteases responsible for the release of the peptides appearing in PP fraction in vivo. In addition, elastase activity in milk PMN was quantified.

\section{MATERIALS AND METHODS}

\section{Endotoxin Infusion}

Ten micrograms of $E$. coli LPS (LPS 026:B6, Sigma Chemical Co, St. Louis, MO) was dissolved in a 10$\mathrm{ml}$ pyrogen-free physiological sodium chloride buffer $(0.9 \%, \mathrm{wt} / \mathrm{vol})$ and infused into a single rear quarter of each of six cows (Moussaoui et al., 2002). Six cows were selected according to the method of Harmon et al. (1990). All quarters were free of both major and minor pathogens, and SCC of each quarter was lower than 100000 cells $/ \mathrm{ml}$. Bulk milk samples for analysis were obtained for 76 -h PI. The 0-h sample corresponded to the milking just before endotoxin infusion. Milk from each of six infused cows was evaluated for all analyses, with the exception of the amino-terminal microsequencing of peptides, where milk from each of the two cows was evaluated.

\section{Preparation of Proteose Peptone}

Skim milk ( $10 \mathrm{ml})$ was heated at $95^{\circ} \mathrm{C}$ for $10 \mathrm{~min}$ and acidified by addition of $1 \mathrm{ml}$ of $10 \%$ ( $\mathrm{vol} / \mathrm{vol}$ ) acetic acid and $1 \mathrm{ml}$ of sodium acetate $1 M$ (Aschaffenburg, 1946). After centrifugation $\left(4000 \mathrm{~g}, 10 \mathrm{~min}, 4^{\circ} \mathrm{C}\right)$, the supernatant containing PP was dialyzed, and the PP were freeze-dried.

\section{Flow Cytometry}

PMN proteolytic activity. A CellProbe reagent, namely AAPV elastase (Beckman Coulter), was used in this study. The cytoenzymologic reagent comprises synthetic nonfluorescent enzyme substrates of two leaving groups conjugated to a dye molecule (Rhodamine 110). The leaving group conjugated to the dye diffuse through the cytoplasmic membrane of live cells and reach the intracellular compartment where the relevant specific intracellular enzyme can cleave the reagent. Cleavage results in the release of the dye within the cell inducing fluorescence that can be detected by flow cytometry. The intensity of the fluorescence emitted is then proportional to the enzymatic activity in each given cell. The letters preceding the reagent indicated the amino acid sequence of the substrate that will be specifically cleaved by the respective enzyme.

Two aliquots of $50 \mu \mathrm{l}$ of washed cells were previously incubated during $10 \mathrm{~min}$ at $37^{\circ} \mathrm{C}$, and $25 \mu \mathrm{l}$ of the appropriate CellProbe was added, and the mix was incubated 10 min at $37^{\circ} \mathrm{C}$. A blank control tube was performed by replacing CellProbe reagent by $25 \mu \mathrm{l}$ of PBS. The enzymatic reaction was then stopped by placing the tubes in crushed ice for at least $10 \mathrm{~min}$. For milk somatic cells, $1 \mathrm{ml}$ of cold PBS was added. Enzymatic activity was analyzed by flow cytometry (EPICS, XL, Beckman Coulter) within the next $15 \mathrm{~min}$ in order to avoid fluorescence release from the cells and background nonspecific labeling. Three gates were defined using a forward scatter/side scatter biparametric histogram, thereby permitting discrimination between lymphocytes, monocytes, and polymorphonuclear neutrophils. A control histogram displaying the same forward scatter ordinate but fluorescence on the abscissa allowed to display the fluorescence intensity of the cell subset. The percentage and mean fluorescence intensity of labeled cells was then recorded using monoparametric histograms.

\section{Proteolysis of Casein in Solution}

Elastase from porcine spleen (5 U/mg of protein; $1 \mathrm{U}$ solubilizes $1 \mathrm{mg}$ of elastin in $2 \mathrm{~min}$ at $\mathrm{pH} 8.8$ and $37^{\circ} \mathrm{C}$ ) was obtained from Sigma. Sodium caseinate $(5 \mathrm{mg} / \mathrm{ml})$ was dissolved in $3 \mathrm{ml}$ of sodium acetate buffer $0.2 \mathrm{M}$, $\mathrm{pH} 7.2$ containing $0.04 \%$ (wt/vol) $\mathrm{NaN}_{3}$. Elastase $(0.02$ $\mathrm{U} / \mathrm{ml}$ final concentration) was added, and the mixture was incubated at $37^{\circ} \mathrm{C}$ for up to $24 \mathrm{~h}$. Aliquots $(200 \mu \mathrm{l})$ were taken periodically for SDS-PAGE analysis. Elastase was inactivated in each aliquot by heating at $100^{\circ} \mathrm{C}$ for 10 min before analysis. CN proteolysis experiments were also performed with other PMN proteases (collagenase, cathepsin $\mathrm{D}$, and cathepsin $\mathrm{G}$ ) and with plasmin in order to determine whether these enzymes played a 
role in the apparition of specific peptides in PP fraction (data not shown).

\section{Peptide Characterization}

SDS-PAGE was performed according to the method of Laemmli and Favre (1973) with a 5\% (wt/vol) polyacrylamide stacking gel in $0.125 M$ Tris- $\mathrm{HCl}(\mathrm{pH} 6.8)$ and with $15 \%$ (wt/vol) polyacrylamide separating gel in $0.38 M$ Tris- $\mathrm{HCl}$ ( $\mathrm{pH} 8.8$ ), in the presence of $0.1 \%$ (wt/ vol) SDS and 5\% (vol/vol) 2-mercaptoethanol. Quantities of $60 \mu \mathrm{g}$ protein per well were loaded in the gel for each PP sample.

Proteins were fixed in gel using $12 \%$ (wt/vol) trichloracetic acid and stained with $0.1 \%$ (wt/vol) Coomassie blue R250 in 50\% (vol/vol) ethanol and 10\% (vol/vol) acetic acid for at least $2 \mathrm{~h}$. Destaining was performed with a solution of $30 \%(\mathrm{vol} / \mathrm{vol})$ ethanol and $7.5 \%$ (vol/ vol) acetic acid. Quantification of the electrophoretic bands was performed by densitometry at $633 \mathrm{~nm}$ (Ultrascan XL densitometer; Pharmacia Fine Chemicals, Uppsala, Sweden), and the concentration of the corresponding peptides or proteins in milk (expressed in $\mathrm{mg} /$ L) was deduced from the PP content in milk (determined by the Kjeldhal method as described by Moussaoui et al., 2002). Glycosylated proteins and peptides were detected in polyacrylamide gel by Schiff's staining after oxidation by $1 \%$ (wt/vol) periodic acid according to the method of Kapitany and Zebrowski (1973).

For microsequencing analysis, proteins were electrotransferred after electrophoresis onto a polyvinylidene difluoride membrane (Immobilon-P, Millipore, Milford, $\mathrm{MA}$ ) for $5 \mathrm{~h}$ at $4^{\circ} \mathrm{C}$ in $10 \mathrm{mM}$ 3-[cyclohexylamino]-1propanesulfonic acid (CAPS) buffer, pH 11 containing 10\% (vol/vol) methanol (Towbin et al., 1979). Proteins were stained with $0.2 \%$ (wt/vol) Ponceau S Red, and the membrane was washed with ultrapure water. After excision, bands of interest were amino-terminal microsequenced by Edman degradation on an automated 476 A protein microsequencer (Applied Biosystems, Foster City, CA).

\section{RESULTS AND DISCUSSION}

\section{PI Proteolytic Activity}

The PP composition change was analyzed by SDSPAGE (Figure 1). Three electrophoretic bands, P1, P2, and P3, appeared from $8 \mathrm{~h}$ PI and disappeared after 36 $\mathrm{h}$ PI for the six cows studied. The apparent MM for P1, $\mathrm{P} 2$, and $\mathrm{P} 3$ was $21.5,17.5$, and $6.0 \mathrm{kDa}$, respectively. These bands were present in milk during the acute inflammatory phase and corresponded to a high concentration of SCC but were absent in physiological "normal" milk. The P1 concentration in milk was maximal

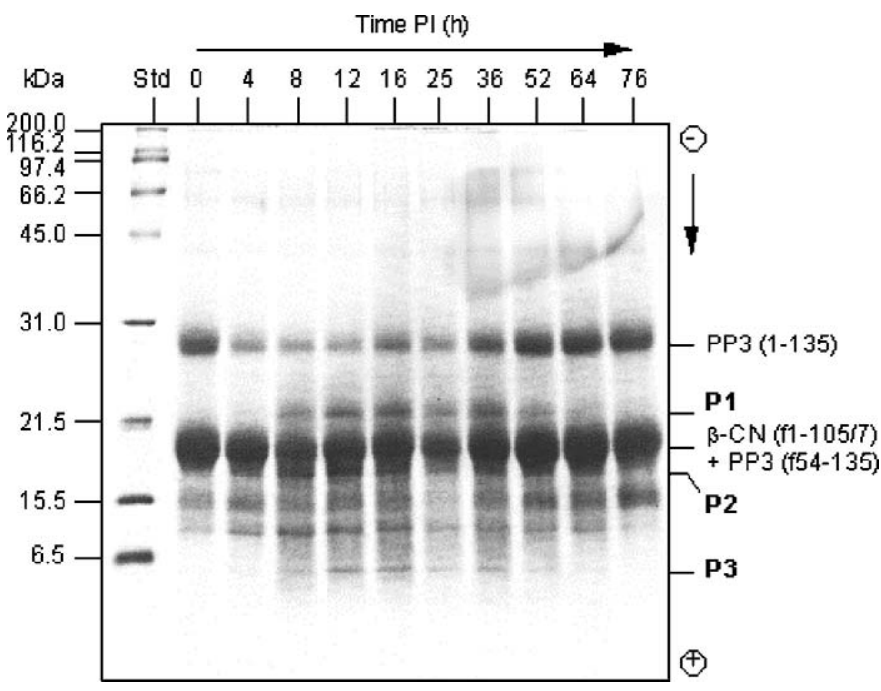

Figure 1. SDS-PAGE profile of proteose peptone (PP) fraction over time. Point $0 \mathrm{~h}$ corresponded to the milking just before the lipopolysaccharide infusion and was a reference milk. An amount of $60 \mu \mathrm{g}$ of protein per well was loaded. Staining was performed with Coomassie blue R 250. P1, P2, and P3 were the three bands appearing in $\mathrm{PP}$ fraction during the experimental mastitis. PI = post infusion. Std $=$ molecular mass standards. Similar electrophoretic patterns were obtained with the six experimental cows.

at $12 \mathrm{~h}$ PI with $160 \pm 32 \mathrm{mg} / \mathrm{L}$, while P2 and P3 concentration in milk was highest at $8 \mathrm{~h}$ PI with $350 \pm 93$ and $92 \pm 44 \mathrm{mg} / \mathrm{L}$, respectively (Table 1 ). The appearance of $\mathrm{P} 1, \mathrm{P} 2$, and $\mathrm{P} 3$ was associated with an increase in the PP content of the milk during the experimental period. The peptides of the three electrophoretic bands might have been generated by cellular proteases rather than plasmin, as plasmin activity was maximum at 4 h PI but displayed a basal level of activity afterwards. Moussaoui et al. (2002) reported that SCC were high $\left(1.2 \times 10^{6}\right.$ to $27 \times 10^{6}$ cells $\left./ \mathrm{ml}\right)$ between 4 and $36 \mathrm{~h} \mathrm{PI}$ (Figure 2). A massive recruitment of immature somatic cells in milk is linked to the inflammatory process and to the permeability of the mammary gland epithelial barrier that is greatly enhanced (Nickerson and Pankey, 1984). In the presence of the toxin (LPS in the present study), the recruited PMN become activated and release functional enzymes through the degranulation process (Jain, 1993). Thus, the relatively high concentration of $\mathrm{P} 1, \mathrm{P} 2$, and $\mathrm{P} 3$ in milk was related to the elevated content of PP at $8 \mathrm{~h}$ PI and might have been due to functional enzymes of activated PMN.

\section{Characterization of the Peptides Contained in P1 to P3}

The three bands $\mathrm{P} 1, \mathrm{P} 2$, and $\mathrm{P} 3$ appearing during the acute phase of inflammation were identified by aminoterminal microsequencing as $\mathrm{CN}$ fragments (Table 2). 


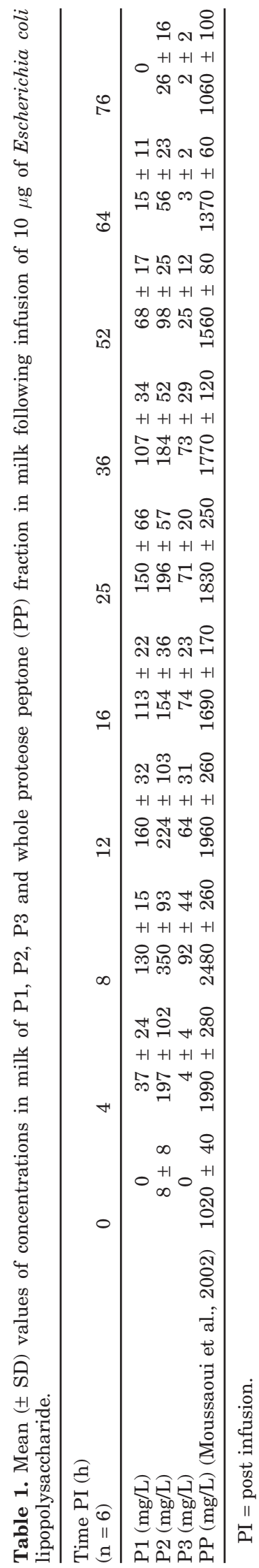

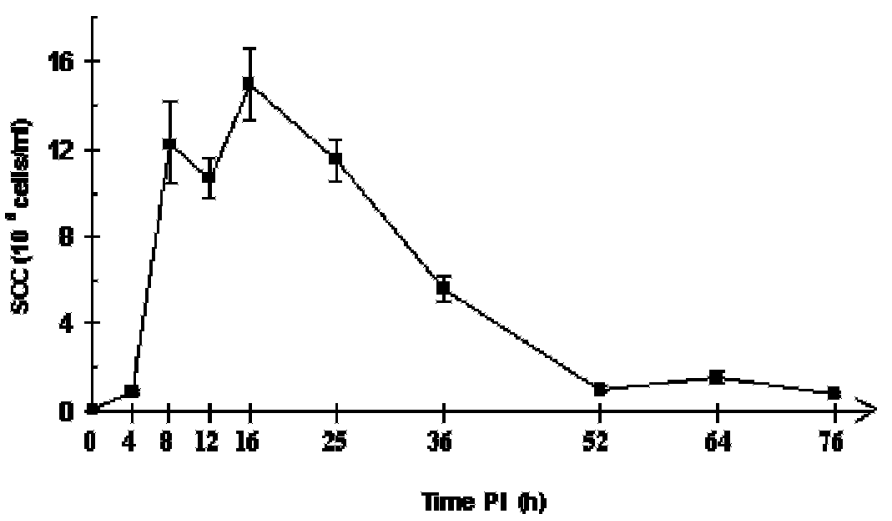

Figure 2. Somatic cell count $\left(\mathrm{SCC}, \times 10^{6}\right.$ cells $\left./ \mathrm{ml}\right)$ in milk over time after intramammary infusion of $10 \mu \mathrm{g}$ of lipopolysaccharide of Escherichia coli according to Moussaoui et al. (2002). Point $0 \mathrm{~h}$ corresponded to the milking just before the lipopolysaccharide infusion and was a reference milk. Where not visible, error bars are included in the symbols. PI = post infusion.

The P1, with apparent MM of $21.5 \mathrm{kDa}$, contained two $\mathrm{CN}$ fragments generated by hydrolysis of $\beta$-CN and $\kappa$-CN, respectively. The first fragment corresponded to the amino-terminal region of $\beta$-CN (accession number in the SwissProt database: P02666; Ribadeau-Dumas et al., 1972). The carboxy-terminal of this $\beta$-CN fragment was, however, not determined due to the complexity of $\mathrm{P} 1$ that contained other minor contaminants. This fragment did not correspond to $\beta$-CN-5P (f1-105/7), the major component of PPs that is released from $\beta$-CN by plasmin action and that has a lower apparent MM of $18 \mathrm{kDa}$ (Girardet et al., 1991). The second fragment was generated by hydrolysis of the $\mathrm{Thr}_{93}-\mathrm{Thr}_{94}$ of $\kappa$-CN (accession number: P02668; Mercier et al., 1973). This cleavage site did not correspond to plasmin specificity and was likely generated by somatic cell proteases. Indeed, SCC were greatly increased during the period in which P1 was present. Hydrolysis of $\kappa$-CN during the mammary gland inflammatory process has never been reported, and $\kappa$-CN is considered to be resistant to endogenous proteolysis (Grieve and Kitchen, 1985). Cleavage sites of $\kappa$-CN by cathepsin D at $\mathrm{Leu}_{32}-\mathrm{Ser}_{33}$, Leu $\mathrm{Lg}^{-}$ $\mathrm{Ser}_{80}$, and $\mathrm{Phe}_{105}-\mathrm{Met}_{106}$ have already been reported (Larsen et al., 1996), but the $\mathrm{Thr}_{93}-\mathrm{Thr}_{94}$ cleavage site has not been described. The $\kappa$-CN fragment might be a short peptide with 12 amino acid residues (fragment 94-105). The last residue identified was $\mathrm{Phe}_{105}$, which corresponds to the characteristic cleavage site $\mathrm{Phe}_{105}{ }^{-}$ Met $_{106}$ of $\kappa$-CN by chymosin (Reid et al., 1997) or cathepsin D (Larsen et al., 1996), that generate glycomacropeptide (GMP). On the other hand, P1 was not revealed by Schiff's reagent staining performed after SDS-PAGE of the PP fraction extracted from milk after $25 \mathrm{~h}$ PI (fraction corresponding to the highest content of $\mathrm{P} 1$; 
Table 1). As the Schiff's reagent staining is not a very sensitive method to detect glycosylated components, a large amount of $\mathrm{PP}(500 \mu \mathrm{g})$ was loaded in the polyacrylamide gel (data not shown). As P1 represented $17 \%$ of $\mathrm{PP}$ (determination by densitometry at $633 \mathrm{~nm}$ ) and $\kappa$ CN peptide $20 \%$ of the peptides in $\mathrm{P} 1$ (estimation by microsequencing), a quantity of $17 \mu \mathrm{g}$ of $\kappa$-CN peptide was calculated for the $500 \mu \mathrm{g}$ of PP loaded in the SDSPAGE gel. This $\kappa$-CN peptide quantity was approximately fourfold higher than that required for detecting glycosylated $\kappa$-CN $(4 \mu \mathrm{g})$ by Schiff's reagent staining (Egito et al., 2001). Thus, P1 did not seem to be glycosylated, and thus, would not include either entirely or partially the GMP, and would not contain $\mathrm{Thr}_{117}$ according to the glycosylation site map of $\kappa$-CN (Pisano et al., 1994). Thus, the carboxy-terminal extremity of the $\kappa$-CN fragment would be located between $\mathrm{Phe}_{105}$ and $\mathrm{Lys}_{116}$. In the case of the cleavage of the Phe $\mathrm{P}_{105^{-}}$ Met $_{106}$ bond (generation of the smallest hypothetical peptide), the PMN proteases responsible for the release of $\kappa$-CN (f94-105) might be cathepsin D (Larsen et al., 1996). Another point was that the $\kappa$-CN fragment, with a maximum theoretical MM of $2.7 \mathrm{kDa}$ (MM of the 94116 fragment), displayed an apparent $\mathrm{MM}$ of $21.5 \mathrm{kDa}$ by SDS-PAGE. The difference between the two MM might be explained by existence of competing equilibria as the $\kappa$-CN fragment might either bind SDS or interact with the $\beta$-CN fragment. Indeed, interactions between individual $\mathrm{CN}$ or between $\mathrm{CN}$ peptides occur and compete with the binding of SDS (Basch et al., 1985).

The P2 contained a peptide originating from $\alpha_{\mathrm{s} 2^{-}} \mathrm{CN}$, but the microsequencing revealed contamination by the neighboring band of fragments $\beta$-CN-5P (f1-105/7) and PP3 (f54-135), as the two bands were not well resolved (Figure 1). The maximum length of the $\alpha_{\mathrm{s} 2}$-CN peptide would be of 84 residues (fragment 123-207 corresponding to the carboxy-terminal region of $\left.\alpha_{\mathrm{s} 2}-\mathrm{CN}\right)$. However, the theoretical MM of $\alpha_{\mathrm{s} 2}$-CN (f123-207) is $10.3 \mathrm{kDa}$ $\left(\alpha_{\mathrm{s} 2}-\mathrm{CN}\right.$ accession number: P02663; Grosclaude et al., 1979), while the apparent MM of P2 was $17.5 \mathrm{kDa}$. In general, the apparent $\mathrm{MM}$ of $\mathrm{CN}$ and $\mathrm{CN}$ peptides determined by SDS-PAGE are overestimated by approximately $5 \mathrm{kDa}$, as the $\mathrm{CN}$ or their peptides either bind SDS or interact with other $\mathrm{CN}$ or peptide molecules (Basch et al., 1985). The cleavage of the $\mathrm{Thr}_{122}-\mathrm{Leu}_{123}$ bond at the amino-terminal side of the $\alpha_{\mathrm{s} 2}$-CN peptide did not result from plasminic hydrolysis, but was likely due to somatic cell protease activity. Elastase, collagenase, and cathepsins are the predominant enzymes in somatic cells (Owen and Campbell, 1999). However, the $\alpha_{\mathrm{s} 2}$ - CN fragment would not be generated by cathepsin $\mathrm{D}$ which cleaves the $\mathrm{Leu}_{123}-\mathrm{Asn}_{124}$ bond; moreover, the carboxy-terminal region of $\alpha_{\mathrm{s} 2}$-CN contains at least two 


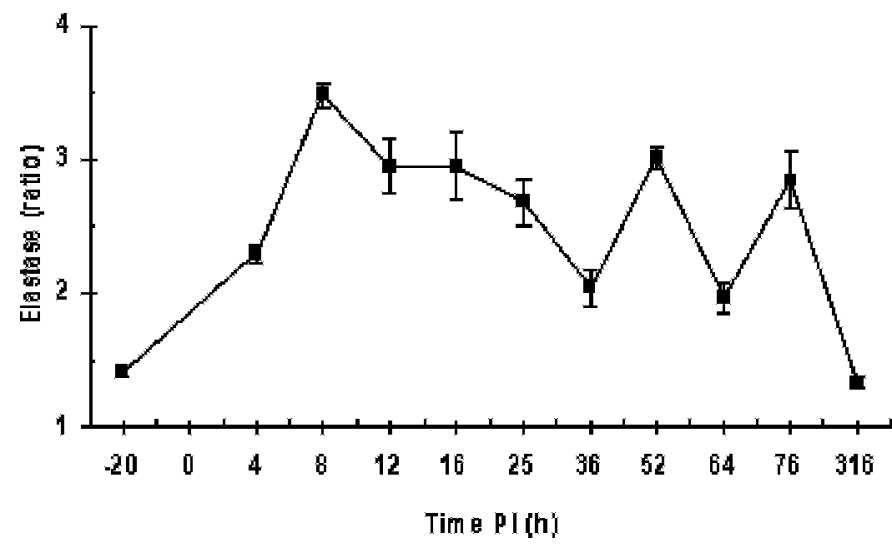

Figure 3. Milk PMN elastase activity over time after intramammary infusion of $10 \mu \mathrm{g}$ of lipopolysaccharide of Escherichia coli. Point $-20 \mathrm{~h}$ corresponded to reference milk. Elastase activity was determined by flow cytometry and expressed, for each point of kinetics, by a ratio of activity related to a blank sample. Where not visible, error bars are included in the symbols. PI = post infusion.

other sites of hydrolysis (Larsen et al., 1996) by cathepsin D $\left(\mathrm{Leu}_{180}-\mathrm{Lys}_{181}\right.$ and $\left.\mathrm{Thr}_{182}-\mathrm{Val}_{183}\right)$.

The P3 contained two CN fragments with an apparent MM of $6.0 \mathrm{kDa}$. These fragments were generated by hydrolysis of the $\mathrm{Asn}_{17}-\mathrm{Glu}_{18}$ bond of $\alpha_{\mathrm{s} 1}-\mathrm{CN}$ (accession number: P02662; Mercier et al., 1971) and of the Gly94$\mathrm{Val}_{95}$ bond of $\beta$-CN (Table 2). Many studies have investigated the cleavage sites of $\alpha_{\mathrm{s} 1}$-CN by proteases such as plasmin (Larsen et al., 1996; Coker et al., 1999), cathepsin D (Larsen et al., 1996), and elastase (Considine et al., 2000). The $\alpha_{\mathrm{s} 1}$-CN fragment of P3 might be due to cathepsin $\mathrm{G}$ or collagenase, since these enzymes hydrolyze peptide bonds at the carboxy-terminal of the Asn residues (Nagano and Ka, 2000). Cleavage sites of $\beta$-CN by several proteases such as collagenase (Gilles and Keil, 1976), cathepsin D (Larsen et al., 1996), and elastase (Considine et al., 1999) have also been previously identified. The $\beta$-CN fragment of P3 might result from a collagenase activity, since collagenase cleaves peptide bonds on carboxy-terminal side of Gly residues (Nagano and Ka, 2000).

\section{Elastase Activity of Milk PMN}

Elastase activity increased as soon as $4 \mathrm{~h}$ PI to reach a maximum of 2.5 times the initial value at $8 \mathrm{~h}$ PI (Figure 3), remained high until $25 \mathrm{~h} \mathrm{PI}$, and dropped at $36 \mathrm{~h}$ PI. Elastase activity rose once again at times 52 and $76 \mathrm{~h}$ PI when the inflammation was over as evidenced by the SCC data (Figure 2) and PP content in milk that was back to its basic level (Table 1). High elastase activity in PMN during inflammation could be explained by the increase of PMN count (PMN represent up to $95 \%$ of somatic cells; Jain, 1993) after LPS

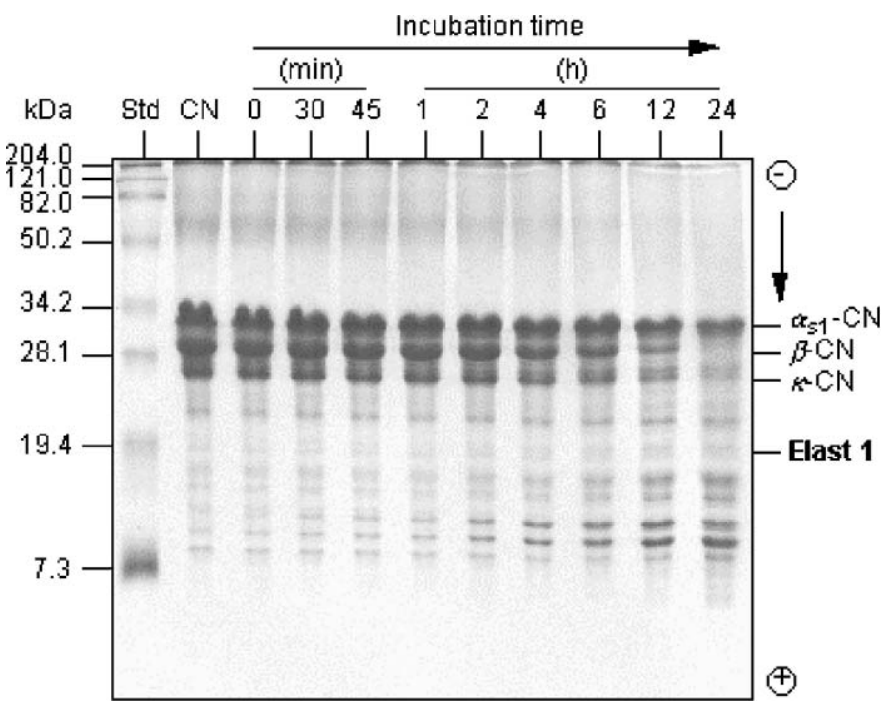

Figure 4. SDS-PAGE profile of hydrolysis kinetics of sodium caseinate by elastase. Sodium caseinate $(5 \mathrm{mg} / \mathrm{ml})$ was incubated with elastase in sodium acetate buffer $0.2 \mathrm{M}, \mathrm{pH} 7.2, \mathrm{NaN}_{3} 0.04 \%$ at $37^{\circ} \mathrm{C}$ up to $24 \mathrm{~h}$. An Enzyme:Substrate ratio of 250 was used. An amount of $20 \mu \mathrm{g}$ of protein per well was loaded. Staining was performed with Coomassie blue $\mathrm{R} 250$. A sample containing sodium caseinate without elastase was incubated $24 \mathrm{~h}$ under identical conditions (CN lane) in order to exclude any bacterial contamination. Std = molecular mass standards. Elast 1 corresponded to a band of apparent molecular mass of $20.3 \mathrm{kDa}$.

infusion (Moussaoui et al., 2002) and cell stimulation that involves high amounts of elastase production (Owen and Campbell, 1999; Bank and Ansorge, 2001).

\section{Hydrolysis of $\mathrm{CN}$ by Elastase in Solution}

In vitro hydrolysis of sodium caseinate by some PMN proteases was performed to identify the enzyme responsible of the generation of at least one of the peptides contained in P1, P2, or P3 bands. Hydrolysis of CN was performed with cathepsins D and G, collagenase, elastase, and mixtures of these enzymes. All combinations with two, three, and four proteases were evaluated. Some SDS-PAGE electrophoretic bands of the CN hydrolysates by cathepsin D and $\mathrm{G}$ and by elastase had apparent MM close to those of P1, P2, or P3 and were amino-terminal microsequenced. These amino-terminal sequences did not correspond to those of the peptides characterized in $\mathrm{P} 1, \mathrm{P} 2$, and $\mathrm{P} 3$, except for a band of $20.3 \mathrm{kDa}$ generated by elastase (Figure 4). The amino-terminal sequence of this band (named Elast 1) corresponded to a single $\beta$-CN amino-terminal fragment, with apparent MM close to that of the $\beta$-CN peptide in P1 (Table 2). Considering the 5-kDa difference between the theoretical and apparent MM of CN peptides, the apparent MM of Elast $1(20.3 \mathrm{kDa})$ was in good agreement with the hypothetical cleavage of the 
$\mathrm{Glu}_{131}-\mathrm{Asn}_{132}$ bond (generation of an amino-terminal peptide with a theoretical MM of $14.8 \mathrm{kDa}$ ), that has been previously characterized by Considine et al. (1999) as a site of hydrolysis of $\beta$-CN by elastase.

No $\kappa$-CN fragment was recovered in Elast 1 and was in contrast to P1. The difference observed between the apparent MM of Elast 1 and P1 might be due to their different ability to bind SDS. Interactions between the $\beta$-CN amino-terminal fragment and SDS would be more important in the absence of the $\kappa$-CN peptide, leading to a faster electrophoretic migration rate for the pure peptide. This supported the hypothesis that Elast 1 and $\mathrm{P} 1$ might contain the same $\beta$-CN fragment.

\section{CONCLUSIONS}

The compositional change of the $\mathrm{PP}$ fraction during the inflammatory process is directly linked to plasmin and PMN protease activities (Le Roux et al., 1995; Moussaoui et al., 2002). Thus, PP would be a good indicator of endogenous proteolysis. The five peptides characterized in P1, P2, and P3 were released by proteases of PMN during the inflammatory process. Elastase, a neutral protease, is excreted from PMN granules during the degranulation phenomenon and acts by an extracellular mechanism of proteolysis (Bank and Ansorge, 2001). The $\beta$-CN peptide of $\mathrm{P} 1$ might be generated by elastase action, which was supported by the high activity of elastase in milk PMN during the period where P1 was present.

\section{ACKNOWLEDGMENTS}

This research was funded by a grant from INRA research program. We thank Franck Saulnier (Service Commun de Séquence des Protéines, Université Henri Poincaré-Nancy 1, France) for microsequencing.

\section{REFERENCES}

Andrews, A. T. 1979. The formation of the structure of some proteosepeptone components. J. Dairy Res. 46:215-218.

Aschaffenbourg, R. 1946. Surface activity and proteins of milk. J. Dairy Res., 14:316-329.

Bank, U. and S. Ansorge. 2001. More than destructive : neutrophilderived serine proteases in cytokine bioactivity control. J. Leukocyte Biol. 69:197-206.

Basch, J. J., F. W. Douglas, Jr., L. G. Procino, V. H. Holsinger, and H. M. Farrell, Jr. 1985. Quantification of caseins and whey proteins of processed milks and whey proteins concentrates, application of gel electrophoresis, and comparison with Harland-Ashworth procedure. J. Dairy Sci. 68:23-31.

Bastian, E. D., and R. J. Brown. 1996. Plasmin in milk and dairy products: an update. Int. Dairy J. 6:435-457.

Brignon, G., B. Ribadeau-Dumas, J. C. Mercier, and J. P. Pelissier. 1977. Complete amino sequence of bovine $\alpha_{\mathrm{s} 2^{-}}$CN. FEBS Lett. 76:274-279.

Coker, C. J., L. K. Creamer, R. G. Burr, and J. P. Hill. 1999. The hydrolysis of $\alpha_{\mathrm{s} 1} \mathrm{CN} \mathrm{A}, \mathrm{B}$, and $\mathrm{C}$ variants by plasmin and chymosin. Int. Dairy J. 9:371-372.
Considine, T., A. Healyn, A. L. Kelly, and P. L. H. McSweeney. 1999. Proteolytic specificity of elastase on bovine $\beta$-CN. Food Chem. 66:463-470.

Considine, T., A. Healyn, A. L. Kelly, and P. L. H. McSweeney. 2000. Proteolytic specificity of elastase on bovine $\alpha_{\mathrm{s} 1}$-CN. Food Chem. 69:19-26.

Egito, A. S., J. M. Girardet, L. Miclo, and J. L. Gaillard. 2001. Highly sensitive periodic acid/Schiff detection of bovine milk glycoproteins electrotransferred after nondenaturing electrophoresis, urea electrophoresis, and isoelectric focusing. Lait 81:775-785.

Eigel, W. N., J. E. Butler, C. A. Ernstrom, H. M. Farrell, V. R. Harwalker, R. Jennes, and R. Whitney. 1984. Nomenclature of proteins of cow's milk: fifth revision. J. Dairy Res. 67:1599-1631.

Gilles, A. M., and B. Keil. 1976. Cleavage of $\beta$-CN by collagenases from Achromobacter iophagus and Chlostridium histolyticum. FEBS Lett. 65:369-372.

Girardet, J. M., A. Mati, T. Sanogo, L. Etienne, L. and G. Linden. 1991. Fast protein liquid chromatography purification of hydrophobic fraction of bovine milk proteose-peptoneproteose peptone and characterization by bidimensional electrophoresis. J. Dairy Res. 58:85-98.

Grieve, P. A., and B. J. Kitchen, 1985. Proteolysis in milk: the significance of proteinases originating from milk leukocytes and a comparison of the action of leukocyte, bacterial, and natural milk proteinases on casein. J. Dairy Sci. 52:101-112.

Grosclaude, F., P. Jourdier, M. F. Mahé. 1979. A genetic and biochemical analysis of a polymorphism of bovine $\alpha_{\mathrm{s} 2}$-casein. J. Dairy Res. 46:211-213.

Hamann, J., and V. Krömker, V. 1997. Potential of specific milk composition variables for cow health management. Livest. Prod. Sci. 48:201-208.

Harmon, R. J., R. J. Eberhardt, D. E. Jasper, B. E. Langlois, and R. A. Wilson. 1990. Microbiological procedures for the diagnosis of bovine udder infection. Natl. Mastitis Council. Arlington, VA.

Jain, N. C. 1993. Page 417 in Essentials of Veterinary Hematology. Lea and Febiger, Philadelphia, PA.

Kanno, C. 1989. Characterization of multiple forms of lactophorin isolated from bovine milk whey. J. Dairy Sci. 72:1732-1739.

Kanno, C., and H. Ogawa. 1989. Proteolytic degradation of lactophorin in skim milk by plasmin and trypsin. Jpn. J. Zootech. Sci. 60:865-873.

Kapitany, R. A., and E. J. Zebrowski. 1973. A high-resolution PAS stain for polyacrylamide gel electrophoresis. Anal. Biochem. 56:361-369.

Laemmli, U. K., and M. Favre. 1973. Maturation of the head of bacteriophage T4. I. DNA packaging events. J. Mol. Biol. 80:575-599.

Larsen, L. B., C. Benfeldt, L. K. Rasmussen, and T. E. Petersen. 1996. Bovine milk procathepsin D and cathepsin D: coagulation and milk protein degradation. J. Dairy Res. 63:119-130

Le Roux, Y., O. Colin, and F. Laurent. 1995. Proteolysis in samples of quarters milk with varying somatic cell counts. 1. Comparison of some indicators of endogenous proteolysis in milk. J Dairy Sci. 78:1289-1297.

Li, X., X. Zhao, and S. Ma. 1999. Secretion of $92 \mathrm{kDa}$ gelatinase (MMP-9) by bovine neutrophils. Vet. Immunol. Immunopathol. 67:247-258

Mercier, J. C., F. Grosclaude, and B. Ribadeau-Dumas. 1971. Structure primaire de la caséine $\alpha_{\mathrm{s} 1} \mathrm{~B}$ bovine. Séquence complète. Eur. J. Biochem. 23:41-51.

Mercier, J. C., G. Brignon, and B. Ribadeau-Dumas. 1973. Structure primaire de la caséine $\kappa \mathrm{B}$ bovine. Séquence complète. Eur. J. Biochem. 35:222-235.

Moussaoui, F., Y. Le Roux, and F. Laurent. 2000. Origines de la protéolyse dans les laits d'une mammite expérimentale à LPS, in 51st annual meeting of the European Association for Animal Production, EAAP, The Hague, Netherlands. 6:224-225.

Moussaoui, F., I. Michelutti, Y. Le Roux, and F. Laurent. 2002. Mechanisms involved in milk endogenous proteolysis induced by a lipopolysaccharide experimental mastitis. J. Dairy Sci. 85:25622570 . 
Nagano, H. and T. Ka. 2000. Purification of collagenase and specificity of its related enzyme of Bacillus subtilis FS-2. Biotechnol. Biochem. 64(1):181-183.

Nickerson, S. C., and J. W. Pankey. 1984. Neutrophils migration through teat and tissues of bovine mammary quarters experimentally challenged with Staphylococcus aureus. J. Dairy Sci. 67:826-834.

Owen, C. A., and E. J. Campbell. 1999. The cell biology of leukocytemediated proteolysis. J. Leukocyte Biol. 65:137-150.

Pisano, A., N. H. Packer, J. W. Redmond, K. L. Williams, and A. A. Gooley. 1994. Characterization of O-linked glycosylation motifs in the glycopeptide domain of bovine $\kappa-\kappa-\mathrm{CN}$. Glycobiology. No. 4, 6:837-844.

Reid, J. R., T. Coolbar, J. S. Ayers, and K. P. Coolbear. (1997). The action of chymosin on $\kappa$ - $\kappa$-Casein and its macropeptide: Effect of $\mathrm{pH}$ and analysis of products of secondary hydrolysis. Int. Dairy J. 7:559-569.

Ribadeau-Dumas, B., G. Brignon, F. Grosclaude, and J. C. Mercier. 1972. Structure de la caséine $\beta$ A2 bovine. Séquence complète. Eur. J. Biochem. 25:505-514.
Rulquin, H. 1997. Régulation de la synthèse et de la sécrétion des constituants du lait chez les ruminants. Renc. Rech. Ruminants 4:327-338.

Saad, A. M., and K. Stensson. 1990. Flow cytofluorometric studies on the alteration of leukocyte populations in blood and milk during endotoxin-induced mastitis in cows. Am. J. Vet. Res. 51:16031607.

Sordillo, L. M., K. Shaefer-Weaver, and D. Derosa. 1997. Bovine immunology of the mammary gland. J. Dairy Sci. 80:1851-1865.

Sorensen, E. S., and T. E. Petersen. 1993. Phosphorylation, glycosylation, and amino acid sequence of component PP3 of the proteosepeptoneproteose peptone fraction of bovine milk. J. Dairy Res. 60(4):534-542.

Towbin, H., T. Staehelin, and J. Gordon. 1979. Electrophoretic transfer of proteins from polyacrylamide gels to nitrocellulose sheets: procedure and some applications. Proc. Natl. Acad. Sci. 76:4350-4354.

Verdi, R. J., and D. M. Barbano. 1991. Properties of proteases from milk somatic cells and blood leukocytes. J. Dairy Sci. 74:20772081 . 